\title{
DAWNE I WSPÓŁCZESNE WALORY TURYSTYCZNE ZIEMI ZABORSKIEJ
}

\section{Wprowadzenie}

Orłowicz w Ilustrowanym przewodniku po województwie Pomorskiem (1924a) oraz w jego odbitce pt. Ilustrowany przewodnik po Ziemi Kaszubskiej (1924b), a więc $w$ jednych $z$ pierwszych $w$ języku polskim przewodnikach po „Ziemi Kaszubów” "1, wydanych przez Książnicę Polską we Lwowie i Warszawie w 1924 r., w interesujący sposób przedstawił Chojnice i wybrane miejscowości dzisiejszego powiatu chojnickiego, w szczególności zamieszkałe przez ludność pochodzenia kaszubskiego. Dawne spojrzenie Orłowicza porównano ze współczesną główną osią turystyczną ziemi chojnickiej, biegnącą od Charzyków do Swornegaci.

W części szczegółowej Ilustrowanego przewodnika po Ziemi Kaszubskiej Orłowicz (1924b, s. 43) rozpoczyna „opis od Chojnic, które, aczkolwiek położone już poza obrębem wsi kaszubskich, sąsiadują z niemi od południa niemal bezpośrednio, a jako centrum administracyjne i handlowe tej okolicy noszą nazwę «stolicy Kaszub Południowych»".

Najczęstszym celem dalszych wycieczek z Chojnic jest jezioro Charzykowskie, które rozpoczyna się $5 \mathrm{~km}$ na północ od miasta, a ciągnie się $12 \mathrm{~km}$ ku północy. Leży ono na poziomie 120 m n.p.m., szerokość jego dochodzi miejscami do 2,5 km, obszaru zajmuje ogółem 1375 ha, jest to zatem jedno z największych jezior województwa Pomorskiego. Głębokość ma ponad $30 \mathrm{~m}$. W jeziorze żyje wiele gatunków ryb i raki. Jego brzegi częściowo zalesione, w stronie południowej i zachodniej zamieszkałe są przez Niemców, w stronie wschodniej i północnej przez Polaków. Brzeg zachodni w jednej trzeciej należy do Niemiec, dlatego też wzdłuż jeziora możliwą jest

${ }^{1}$ Wcześniej ukazały się w języku polskim tylko dwa przewodniki: Bernarda Chrzanowskiego - przewodnik po miejscowościach nadmorskich Na kaszubskim brzegu oraz Aleksandra Majkowskiego Przewodnik po Szwajcarii Kaszubskiej. 
wycieczka jedynie brzegiem wschodnim do Swornigacu ( $23 \mathrm{~km}$ z Chojnic) przez wieś Bachorze. $6 \mathrm{~km}$ od Chojnic leży na południowym brzegu jeziora niemiecka wioska Charzykowo, letnisko podmiejskie, z kilkoma willami, pensjonatami i restauracjami. Nad jeziorem łazienki, gdzie można wynajmować też łodzie do wycieczek (Orłowicz, 1924b, s. 44).

Droga z Chojnic prowadzi gościńcem bytowskim, zbaczającym w lewo od ulicy Strzeleckiej, który w odległości 3 km, od miasta stanowi na przestrzeni $3 \mathrm{~km}$ granicę polsko-niemiecką. Po drodze mija się kilka restauracji podmiejskich. Do większych osad zaborskich ${ }^{2}$ już w XIII w. należał m.in. Swornigac. Jest to duża wieś kaszubska o 1300 mieszkańcach, położona na północnym brzegu 600 ha dużego jeziora Karsino (120 m n.p.m.) po obydwóch brzegach Brdy. Naprzeciw poczty gospoda z restauracją Gliszczyńskiego. Okolica piaszczysta. Wieś jest starą osada, gdzie już w r. 1272 istniał klasztor Augustianów, bogato obdarowany przez książąt pomorskich. W r. 1303 tutejszy klasztor połączył się z klasztorem Cystersów w Oliwie. W r. 1333 odstąpili Cystersi wieś krzyżakom, poczem należała do komturstwa tucholskiego. Obecnie istnieją tu dwa kościoły. Nowy kościół murowany, neobarokowy, zbudowany w r. 1913 ozdobiony jest polichromją braci Drapiewskich. Dzwon z r. 1700 odlewał Absalon Wittwerck. Kościół stary, drewniany z r. 1742, z wieża, filialny do Konarzyna, dość malowniczy, stoi na wzgórzu, gdzie niegdyś stał folwark krzyżacki, $\mathrm{z}$ którego piękny widok na bogatą $\mathrm{w}$ jeziora okolicę. Jest on obecnie nieużywany i opuszczony (Orłowicz, 1924b, s. 46).

Jezioro Karsino, nad którem leży Swornigac ma 4 km długości, a na jego południowym brzegu, na wąskim przesmyku między niem, a jeziorem Charzykowskim leży Swornigac Nowy (Małe Swornegacie). Brzegami tych jezior można odbyć całodzienną przechadzkę $(27 \mathrm{~km})$ do Chojnic. Droga wiedzie wschodnim, polskim brzegiem, przeważnie lasem, a z wysokich brzegów piękne i urozmaicone widoki na jezioro. Niedaleko leśniczówki Bachórz. Stary krzyż przydrożny, oznacza najpiękniejszy punkt widokowy (na Jezioro Charzykowskie) (Orłowicz, 1924b, s. 47).

\section{Turystyka na ziemi chojnickiej}

W 2021 r., czyli po 97 latach od czasu publikacji przewodnika Orłowicza, ta część ziemi chojnickiej, często określana jako ziemia zaborska, to obszar wciąż nieznacznie przekształcony przez człowieka, wymarzony do

\footnotetext{
${ }^{2}$ Nazwa Zabory dotyczyła terenów zamieszkałych przez ludność kaszubską a więc ziem obejmujących za czasów krzyżackich północną część komturstwa tucholskiego - między Jeziorem Charzykowskim, Brdą, Struga, Czarną Wodą a Jeziorem Sumińskim. Nazwa ta oznaczała ziemię położoną „za borami” względem ówczesnej kasztelanii raciąskiej (Ostrowski, 2009).
} 
uprawiania ekoturystyki. Tu w 1990 r. utworzono Zaborski Park Krajobrazowy (ZPK). Powstał on w celu ochrony i popularyzacji dziedzictwa przyrodniczego, kulturowego i krajobrazu północno-zachodniej części Borów Tucholskich. W 1996 r. w południowej części ZPK, w rejonie Strugi Siedmiu Jezior, powołano Park Narodowy „Bory Tucholskie”. Obecnie 60\% Zaborskiego Parku Krajobrazowego znajduje się w gminie Brusy, a 40\% w gminie Chojnice. W 2010 r. Międzynarodowa Rada Koordynacyjna programu UNESCO „Człowiek i Biosfera” uznała Bory Tucholskie, w tym obszar ZPK, za Rezerwat Biosfery. W Polsce jedenaście rezerwatów biosfery wpisano na listę UNESCO MAB, a Rezerwat Biosfery Bory Tucholskie jest drugim pod względem wielkości (Gierańczyk, 2015).

Na sandrowym terenie Zaborskiego Parku Krajobrazowego dominują lasy, głównie bory sosnowe tworzące parasol ochronny dla czystych jezior i licznych torfowisk, a także dające schronienie występującym tu zwierzętom. Bory Tucholskie, w tym Zaborski Park Krajobrazowy, cenione są przez przyrodników w Polsce i za granicą. Obszar Zaborskiego Parku Krajobrazowego jest idealny do uprawiania turystyki krajoznawczej oraz rozwoju ekoturystyki. Wyznaczone szlaki piesze $(150 \mathrm{~km})$, rowerowe $(136 \mathrm{~km})$ i kajakowe $(87 \mathrm{~km})$ stanowią najbardziej atrakcyjne krajobrazowo, przyrodniczo i turystycznie trasy (Gminny Ośrodek Kultury w Chojnicach, 2020).

Jezioro Charzykowskie (Łukomie) położone jest na terenie Zaborskiego Parku Krajobrazowego w pobliżu granicy parku narodowego, to akwen o szczególnych walorach przyrodniczo-krajobrazowych. Przez jezioro wiedzie szlak kajakowy Brdy, zaś wokół akwenu turyści mogą poruszać się trasami pieszymi i rowerowymi. Rzeka Brda łączy to jezioro z jeziorami Długim i Karsińskim, a dalej (poniżej Swornegaci) z jeziorami Witoczno, Łąckim i Dybrzk, także znajdującymi się na terenie ZPK. Szlak Brdy uznawany jest za jeden z najatrakcyjniejszych w Europie. Jezioro Charzykowskie to prawdziwy raj dla miłośników wody i sportów wodnych. Piękne leśne otoczenie, czysta przyroda i bogata oferta usług turystycznych sprawiają że miejsce to cieszy się dużą popularnością (fot. 1).

Obecnie ruch turystyczny skupia się w centrum powiatu chojnickiego, w gminie Chojnice, której zasadniczą oś stanowią akweny jezior: Charzykowskiego, Długiego i Karsińskiego. Wokół nich usytuowały się najważniejsze miejscowości turystyczne i letniskowe, takie jak Charzykowy, Swornegacie i Małe Swornegacie (fot. 2).

Do gminy Chojnice należy interesujący obszar, na terenie którego znajduje się 50 jezior, Park Narodowy „Bory Tucholskie” oraz Zaborski Park 


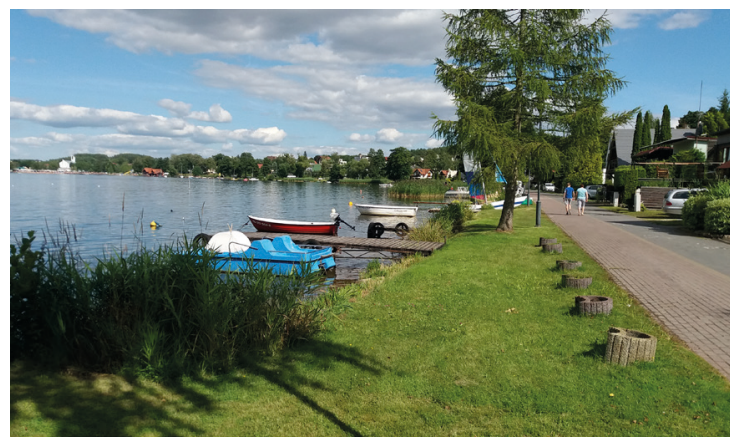

Fotografia 1. Promenada i ścieżka rowerowa nad jeziorem w Charzykowach Źródło: T. Palmowski (2020)

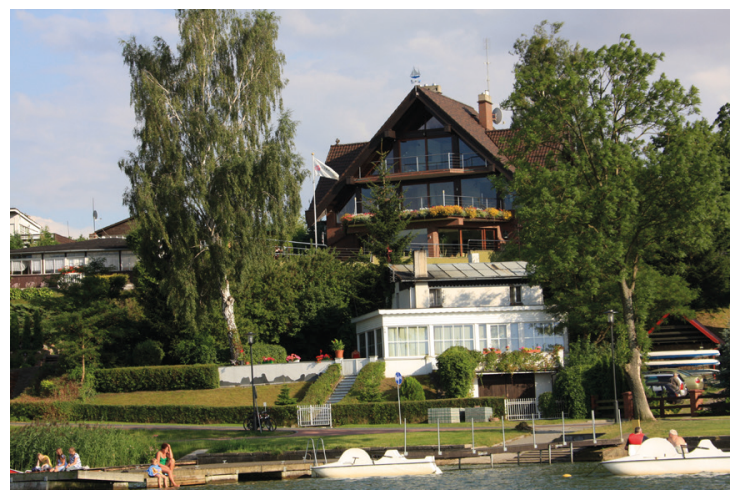

Fotografia 2. Zabudowa letniskowa w Charzykowach Źródło: T. Palmowski (2020)

Krajobrazowy odwiedzany przez około 100 tys. osób rocznie. Dobrze czują się tu zarówno turyści przyjeżdżający na wczasy pobytowe, preferujący wypoczynek czynny, np. kajakarze, żeglarze, wędkarze, grzybiarze, jak i miłośnicy wycieczek pieszych, rowerowych i konnych. Gmina dysponuje ogromnym potencjałem turystycznym, pokaźną bazą hotelową pensjonatową oraz agroturystyczną (Gminny Ośrodek Kultury w Chojnicach, 2020).

Udział liczby turystów odwiedzających gminę Chojnice w porównaniu do całego powiatu od lat przekracza 50\% i wykazuje tendencję wzrostową - do ok. 70\% w 2020 r. W tym właśnie roku w gminnej ewidencji usług hotelarskich odnotowano 81 podmiotów turystycznych działających na terenie gminy, w tym 12 ośrodków wypoczynkowych, 14 gospodarstw 
agroturystycznych, 7 pól namiotowych. Pozostałe to kwatery prywatne, apartamenty i pokoje gościnne ${ }^{3}$ (Urząd Gminy Chojnice, 2020).

Według stanu na 2020 r. w Charzykowach mieszkają 1963 osoby, jest tam 511 miejsc noclegowych całorocznych i 370 sezonowych, 5 sklepów, 14 obiektów gastronomicznych (Urząd Gminy Chojnice, 2020). Miejscowość Charzykowy założona została przez Krzyżaków w 1350 r., funkcję letniskową zaczęła pełnić w 1895 r., kiedy dr Maibauer kupił tam willę z urokliwym widokiem na jezioro (Sołectwo Charzykowy, 2020), a zapraszani przez niego goście rozpropagowali to miejsce. Dzisiaj Charzykowy to duża miejscowość letniskowa, usytuowana na północny zachód od Chojnic, przy południowym krańcu jeziora Charzykowskiego. Miejscowość jest największym w powiecie chojnickim centrum turystyki, a także znanym w kraju i za granicą ośrodkiem żeglarstwa oraz sportów wodnych. Tu powstał pierwszy w Polsce Klub Żeglarski (Gierszewski, 2008; Knopek, 2018), a swoje siedziby mają Zaborski Park Krajobrazowy i Park Narodowy „Bory Tucholskie”. Wzdłuż brzegu jeziora Charzykowskiego można spacerować po ponad 4-kilometrowej promenadzie, przy której zlokalizowano nowoczesny port jachtowy.

Tradycje żeglarskie jeziora i znajdujących się nad nim ośrodków sportów wodnych sięgają okresu międzywojennego, kiedy to Charzykowy stały się centrum polskich sportów wodnych, ze szczególnym uwzględnieniem żeglarstwa i bojerów. Do dziś w miejscowości mieści się siedziba Chojnickiego Klubu Żeglarskiego, najstarszego w Polsce klubu żeglarskiego ${ }^{4}$. Powstał on prawie jednocześnie z odradzającą się po latach zaborów Polską. Pierwsze regaty na Jeziorze Charzykowskim zorganizowano już w 1920 r. i od tego czasu Charzykowy stały się żeglarską stolicą Polski.

Obecnie Chojnicki Klub Żeglarski zarządza jednym z najnowocześniejszych portów jachtowych, który może przyjmować jednostki pływające różnych klas (fot. 3). Wyposażony jest w trzy pomosty pływające i dwa stałe, ma 160 miejsc postojowych, w tym 80 przy pomostach pływających i 80 przy pomostach stałych. W porcie znajduje się dźwig do wodowania jachtów, slip do wodowania wózków podłodziowych, cztery slipy do wodowania łodzi regatowych, a także punkty do poboru energii

${ }^{3}$ Faktyczna liczba podmiotów turystycznych może być znacznie większa, gdyż nie wszystkie obiekty zostały zgłoszone do ewidencji.

${ }_{4}^{4}$ Chojnicki Klub Żeglarski założony został w 1922 r. W 2017 r. uroczyście obchodzono 95. rocznicę jego powstania (Ostrowski, 2009; Gminny Ośrodek Kultury w Chojnicach, 2020). 
elektrycznej, wody i zrzucania ścieków (Marina Charzykowy, 2020). Żeglarze mogą korzystać z bogatego zaplecza techniczno-sanitarnego. Całość dopełnia ogólnodostępna wieża, będąca świetnym punktem widokowym na jezioro, na którym rozgrywanych jest wiele imprez żeglarskich, m.in. regat i szkoleń dla młodzieży. Zima, o ile mróz skuje taflę jeziora grubym lodem, zamienia się ono w znakomite lodowisko do regat bojerowych.

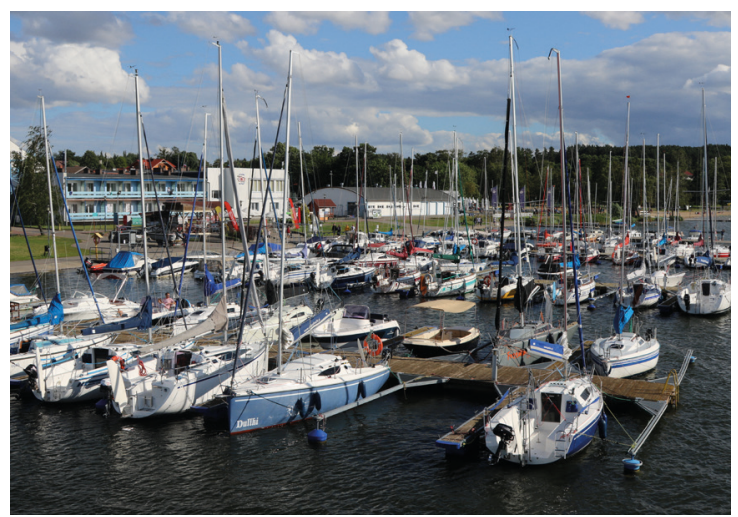

Fotografia 3. Port jachtowy w Charzykowach, na drugim planie Chojnicki Klub Żeglarski Źródło: T. Palmowski (2020)

Położona nad jeziorem miejscowość Charzykowy zapewnia pełne zaplecze gastronomiczne, noclegowe i sportowe $-\mathrm{z}$ restauracjami, pensjonatami, kąpieliskami i wypożyczalniami sprzętu wodnego. W Charzykowach funkcjonuje kilkanaście podmiotów zajmujących się wyłącznie turystyką. Powstają tam mniejsze i większe wille, domy letniskowe i hotele. W lipcu 2018 r. oddano do użytku komfortowy hotel czterogwiazdkowy, mający 155 miejsc noclegowych (Urząd Gminy Chojnice, 2020). Główną atrakcją miejscowości jest jezioro, ale można skorzystać z wielu form spędzania wolnego czasu zarówno na wodzie, jak i na lądzie. Strzeżone kąpielisko i piaszczysta plaża to jedne z najbardziej obleganych przez gości miejsc, do dyspozycji turystów pozostaje również zespół boisk do gier plażowych oraz plac zabaw dla dzieci. W 2020 r. uruchomiono zjeżdżalnie wodne, cieszące się wielką popularnością szczególnie wśród młodszych użytkowników. Jest też ogromny pomost gminny, który w końcu 2020 r. został zmodernizowany. Przy pomoście obok plaży cumuje statek piracki „TUR" - w sezonie letnim kilka razy dziennie wypływa z turystami $\mathrm{w}$ rejsy po jeziorze, $\mathrm{w}$ trakcie których z pokładu można podziwiać dwie 


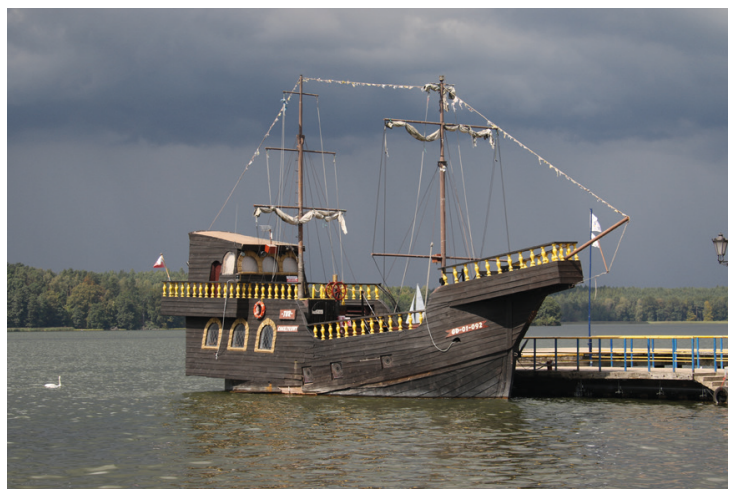

Fotografia 4. Statek „Tur” przy pomoście w Charzykowach Źródło: T. Palmowski (2020)

urokliwe wyspy - Wyspę Miłości i Wyspę Miłości dla Zaawansowanych55, a także malownicze zatoki (fot. 4).

W pogodne dni z promenady i wysokich zboczy obserwować można na jeziorze białe żagle małych i dużych łodzi oraz jachtów. Dostrzec i usłyszeć można także szybkie i coraz mniej głośne motorówki i skutery, a nawet powolne i majestatyczne hausbooty (pływające domki). Turyści w wielu punktach mogą bez problemu wypożyczyć nie tylko kajaki, łódki wiosłowe czy rowery wodne, ale także żaglówki i motorówki. Jest to również atrakcyjny akwen dla wędkarzy.

Poza wydarzeniami sportowymi i turystycznymi odbywającymi się na wodzie, nad brzegiem akwenu mają miejsce wydarzenia kulturalno-muzyczne, nawiązujące do lokalnych tradycji żeglarskich. W Charzykowach wcześniej istniała mała muszla koncertowa, a od $1997 \mathrm{r}$. intensywnie funkcjonuje duży Amfiteatr im. Ottona Weilanda, w którym w letnie weekendy odbywają się ciekawe imprezy plenerowe ${ }^{6}$. Najważniejszym letnim wydarzeniem o charakterze kulturalnym, organizowanym w drugi weekend sierpnia, jest Festiwal Piosenki Żeglarskiej. Impreza ta od 23 lat rokrocznie ściąga do Charzyków liczne grono fanów, przyzwyczajonych do wysokiego poziomu artystycznego oraz niezwykłego klimatu stworzonego przez lokalne środowisko żeglarskie, skupione wokół dwóch klubów żeglarskich ${ }^{7}$. Imprezę tę zalicza się do flagowej piątki wydarzeń szantowych w Polsce. Koncerty profesjonalistów przeplatane

${ }^{5}$ Inna nazwa tej wyspy to Wyspa Bachorska, nawiązuje ona do pobliskiej osady Bachorze.

${ }^{6}$ Bogatą ofertę wydarzeń przygotowuje Gminny Ośrodek Kultury w Chojnicach.

7 Chojnickiego Klubu Żeglarskiego i Ludowego Klubu Sportowego (LKS). 
są zespołami konkursowymi, które rywalizują o „Wielki Pagaj Ottona Weilanda" 8 . Innym ciekawym wydarzeniem są nocne projekcje filmów na dużym ekranie, w ramach programu „Filmowe lato w zasięgu Oran-

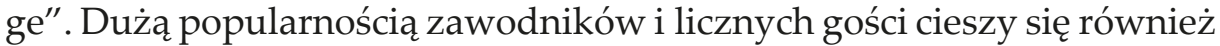
triathlon, którego trasa wiedzie przez jezioro i wokół niego (Gminny Ośrodek Kultury w Chojnicach, 2020).

W amfiteatrze w ostatnią sobotę lipca organizowany jest Jarmark Ekoturystyczny (w 2019 r. odbyła się XI edycja). Ma on na celu promocję Rezerwatu Biosfery Bory Tucholskie oraz jego darów natury i kultury. Oprócz prezentacji twórczości rękodzielniczej oraz wyrobów spożywczych charakterystycznych dla Borów Tucholskich, impreza ta jest okazją do poznawania niezwykle cennych zasobów przyrodniczych Borów Tucholskich oraz bogatej i różnorodnej działalności lokalnych parków, nadleśnictw i podmiotów edukacyjnych (Gminny Ośrodek Kultury w Chojnicach, 2020).

Od 2016 r. Centrum Edukacji Przyrodniczej Parku Narodowego „Bory Tucholskie” przez cały rok prowadzi zajęcia edukacyjne o tematyce przyrodniczej, zielone szkoły oraz organizuje wystawy i prelekcje. Od 2019 r. turyści, grupy szkolne oraz lokalni mieszkańcy mogą poznać nie tylko zwierzęta gospodarskie rodzimych ras, ale także zwierzęta dziko występujące $\mathrm{w}$ przyrodzie, które nie mogą powrócić do swojego naturalnego środowiska. Na terenie Parku prowadzone są również wycieczki i zajęcia w terenie (Centrum Edukacji Przyrodniczej Parku Narodowego „Bory Tucholskie", 2020).

Funka to miejscowość zamieszkana przez 133 osoby, dostępne są tam 363 miejsca noclegowe całoroczne i 555 sezonowych (stan na 2020 r.) (Urząd Gminy Chojnice, 2020). W Funce, pośród sosnowego lasu, w 1936 r. zbudowano Harcerski Ośrodek Wodny. Od tego czasu w miejscu tym organizuje się obozy żeglarskie i inne związane z uprawianiem sportów wodnych, a podczas letniego wypoczynku młodzież z całej Polski uczy się tam trudnej sztuki żeglowania. Wielu znanych w Polsce żeglarzy rozpoczynało w Funce swoją żeglarską przygodę i do dziś wspomina to miejsce $z$ sentymentem (fot. 5).

Obecnie Harcerskie Centrum Edukacji Ekologicznej i Harcerski Ośrodek Wodny to duży ośrodek wypoczynkowy w samym sercu Borów Tucholskich, na terenie Zaborskiego Parku Krajobrazowego. Zajmuje teren o powierzchni 9,5 ha, ma liczne miejsca noclegowe, 11 pomieszczeń

${ }^{8}$ Otton Weiland był nestorem żeglarstwa chojnicko-charzykowskiego. Poświęcona jemu tablica znajduje się przed Chojnickim Klubem Żeglarskim w Charzykowach. 


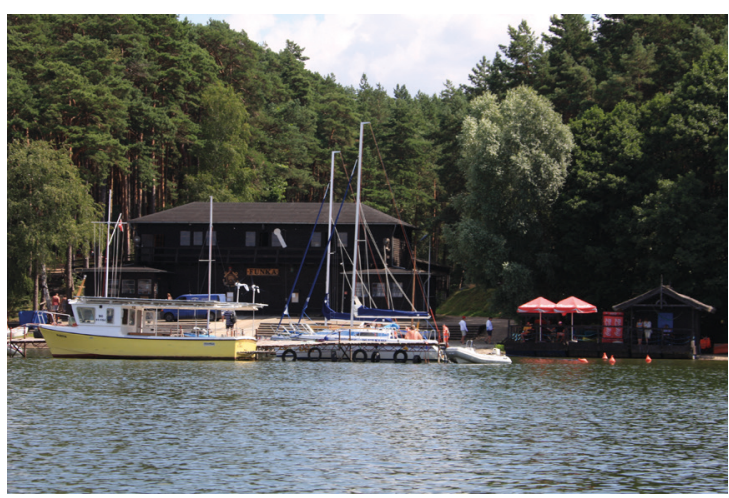

Fotografia 5. Stanica harcerska w Funce Źródło: T. Palmowski (2019)

dydaktycznych oraz świetlice bogato wyposażone w techniczne środki nauczania. Dysponuje także bogatym terenowym zapleczem dydaktycznym, w skład którego wchodzi siedem specjalistycznych ścieżek dydaktycznych, ścieżka zdrowia i uprawowy ogród ekologiczny. Do tego dochodzi łódź naukowo-dydaktyczna, rowery, kajaki i żaglówki. W Funce odbywają się ponadto plenery malarskie "Jesień, jesien, ach to Ty” (Gminny Ośrodek Kultury w Chojnicach, 2020).

Bachorze $^{9}$ (12 mieszkańców, 2020 r.) to niewielka osada usytuowana nad wschodnim brzegiem jeziora Charzykowskiego, dziś o charakterze letniskowym. Jej początki sięgają XVIII w. W Bachorzu znajduje się Ośrodek Rehabilitacyjno-Wypoczynkowy Natura (cztery pawilony i cztery pozostałe budynki). Ponadto są tu cztery domy mieszkalne oraz dwa domy letniskowe. Tuż przy szosie prowadzącej w kierunku Małych Swornegaci do dziś stoi drewniany krzyż, wspomniany przez Orłowicza w 1924 r., jego geneza sięga prawdopodobnie 1812 r. (Gmina Chojnice, 2013) (fot. 6). Spoglądając z miejsca jego usadowienia w kierunku jeziora Charzykowskiego, obserwować można przepiękny widok na jezioro, wyspę i położone po drugiej stronie jeziora lasy. Na wyspie znajduje się stanowisko archeologiczne, obejmujące obozowisko z X-XIII w.

Według stanu na 2020 r. Małe Swornegacie zamieszkuje 68 osób, jest tam 10 miejsc noclegowych całorocznych i 98 sezonowych, pole namiotowe, jeden sklep, dwa punkty gastronomiczne (Urząd Gminy Chojnice, 2020). Ta niewielka miejscowość położona jest na przesmyku między jeziorami Charzykowskim i Karsińskim, oddzielonymi wąskim półwyspem od

9 Nazwa Bachorz w języku prasłowiańskim oznacza bagno, moczary. 


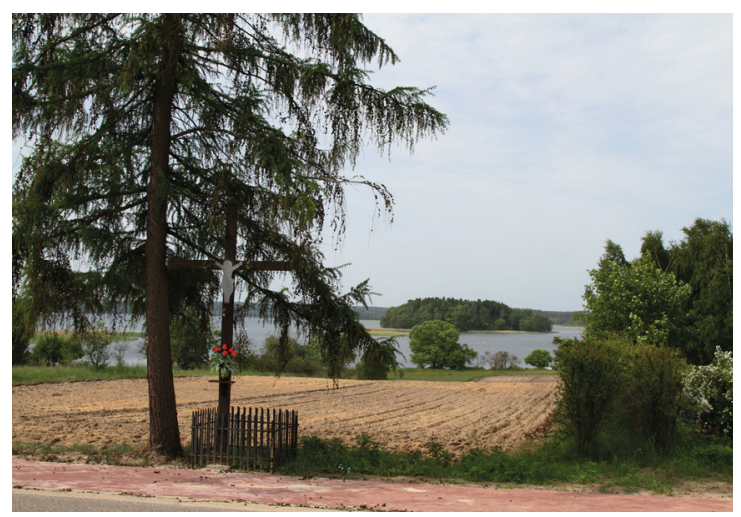

Fotografia 6. Krzyż oraz najpiękniejszy, według Orłowicza, widok na jezioro Charzykowskie Źródło: T. Palmowski (2020)

jeziora Długiego. Korzenie wsi sięgają średniowiecza, w XVIII w. była osadą leśną (Zwoliński, 2019). W 2013 r. zbudowano most zwodzony, aby umożliwić żeglarzom swobodny przepływ z jeziora Charzykowskiego na jeziora Długie i Karsińskie w kierunku Swornegaci. Latem jest on podnoszony cztery razy w ciągu doby i stanowi znaczącą atrakcję, podziwianą przez turystów. Dużą popularnością zarówno wśród żeglarzy, jak i innych gości cieszy się plaża z niewielką przystanią i usytuowanym przy niej małym lokalem gastronomicznym.

Chociński Młyn (25 mieszkańców, 2020 r.) to mała osada leśna położona nad rzeką Chociną, pomiędzy Konarzynami a Swornegaciami. Znajdują się tu pozostałości drewnianego tartaku, który kiedyś miał podsiębierne koło wodne. Jest to jedno z miejsc, gdzie rozpoczynają się krótkie spływy kajakowe meandrami rzeki Chociny do jeziora Karsińskiego (Palmowski, 1997).

Swornegacie ${ }^{10}$ według stanu na 2020 r. ma 601 mieszkańców, 264 miejsca noclegowe całoroczne i 190 sezonowych, pole namiotowe, dwa sklepy, 10 obiektów gastronomicznych (Urząd Gminy Chojnice, 2020). Jest to obecnie jedna z największych miejscowości południowych Kaszub. Swornegacie stanowią niezwykle urokliwą i malowniczo usytuowaną typową wieś kaszubska, zlokalizowaną w gminie Chojnice. Miejscowość wyróżnia się ogromną dynamiką ruchu turystycznego, dzięki czemu

10 Według autora nazwa miejscowości pochodzi od ogacania (umacniania przy pomocy faszyny, czyli uplecionych z wikliny i sosnowych korzeni warkoczy) brzegów rzeki Brdy i sąsiednich jezior. 
większość mieszkańców zarabia na turystyce, na dużą skalę rozwinęła się też agroturystyka. Przez Swornegacie przepływa rzeka Brda, a więc w miejscowości rozpoczynają się i kończą liczne spływy kajakowe, co sprawia, że miejsce jest uznawane za stolicę agroturystyki i kajakarstwa.

Dominantę architektoniczną miejscowości tworzy neobarokowy kościół pw. Świętej Barbary. Jego sylwetka nawiązuje do kaszubsko-pomorskiej tradycji architektonicznej. Stary, drewniany kościółek z 1742 r. przeniesiony został w 1980 r. do Kaszubskiego Parku Etnograficznego we Wdzydzach Kiszewskich.

Od 2005 r. lokalne wyroby artystyczne można podziwiać i nabywać w Kaszubskim Domu Rękodzieła Ludowego (fot. 7). Stała wystawa prezentuje zbiory dokumentujące życie codzienne Zaboraków od połowy XIX w. Od 2020 r. ekspozycja wzbogaciła się o kolejne eksponaty związane ze szkolnictwem, rybołówstwem i handlem. Cyklicznie organizowane są wystawy malarstwa i rzeźby kaszubskich twórców. Działa tam też punkt informacji turystycznej. W sezonie letnim miejsce to odwiedza prawie 55 tys. gości (2019 r.) (Urząd Gminy Chojnice, 2020).

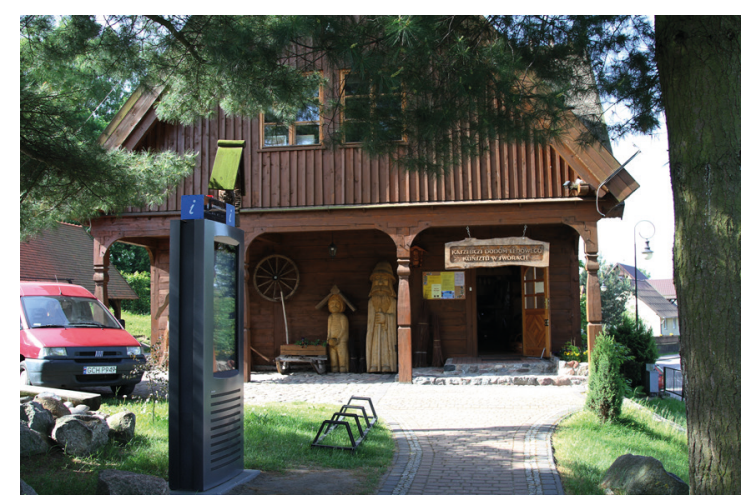

Fotografia 7. Kaszubski Dom Rękodzieła Ludowego w Swornegaciach Źródło: T. Palmowski (2020)

W okresie wakacji letnich w Swornegaciach odbywają się spotkania z twórcami i muzykami, którzy na dziedzińcu Kaszubskiego Domu Rękodzieła Ludowego prezentują ludowe pieśni, bajki, dowcipy w języku kaszubskim, kaszubskie śpiewy oraz tańce i zabawy. W każdym ze spotkań uczestniczy 150-200 osób. Dużą atrakcją jest też możliwość skosztowania dań kuchni regionalnej, np. kucha na młodzach, chleba ze smalcem i kiszonym ogórkiem czy zwykłej brejki. Można też zapoznać się 
z tajnikami wyplatania faszyny, a u hafciarek z zasadami wyszywania obowiązującymi w regionie.

Od 2000 r. wiele koncertów i innych wydarzeń skupiających uwage gości w sezonie wakacyjnym odbywa się na scenie letniego amfiteatru w Swornegaciach. Z kolei podczas organizowanej w połowie sierpnia gry terenowej „Test Kaszuba” ok. 500 gości zapoznaje się z historią regionu, jego kultura, językiem kaszubskim i realiami życia codziennego mieszkańców południowych Kaszub. W Swornegaciach organizowane są ponadto Kaszubskie Regaty Wioślarskie im. Bolesława Drewka (Gminny Ośrodek Kultury w Chojnicach, 2020).

Kajakarze wypływają ze Swornegaci lub są dowożeni na szlaki kajakowe Zbrzycy (fot. 8), Chociny i Brdy. Dzięki wsparciu z Europejskiego Funduszu Rozwoju Regionalnego i projektowi „Pomorskie Szlaki Kajakowe - meandry Brdy i Chociny" do końca 2020 r. wykonano kompleksowe zagospodarowanie szlaków wodnych, zbudowano sześć przystani kajakowych, w tym na Chocinie w Chocińskim Młynie oraz na szlaku Brdy w Swornegaciach, Kokoszce i nad jeziorem Witoczno (przystań PTTK). Nowe elementy infrastruktury turystycznej to pomosty do wodowania i wyciągania kajaków, suszarki do kajaków, wiaty, zatoki postojowe, miejsce na ognisko, sanitariaty, tablice informacyjne i drogi dojazdowe. Cyklicznie organizowany jest tam Wielki Spływ Kajakowy Brdą (Gminny Ośrodek Kultury w Chojnicach, 2020).

Powiat chojnicki słynie w całym kraju ze ścieżek rowerowych, oplatających największe atrakcje turystyczne tego obszaru. W szczególności dotyczy to tzw. Kaszubskiej Marszruty, czyli sieci ścieżek i szlaków

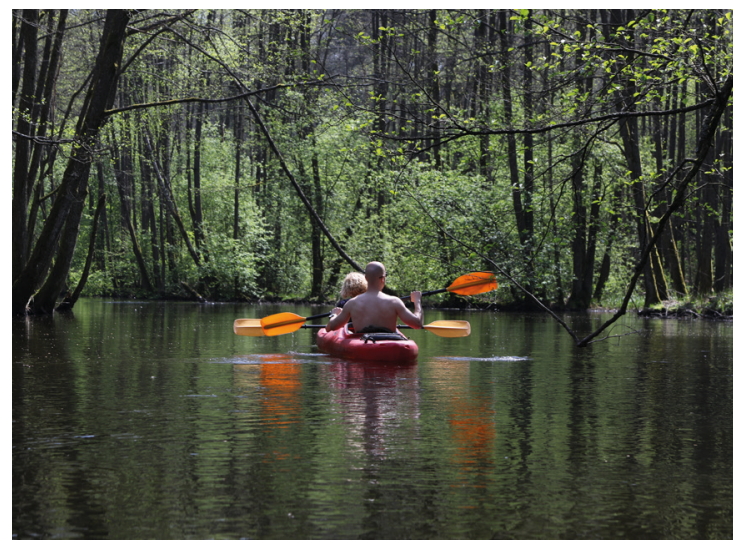

Fotografia 8. Kajakarze na Zbrzycy Źródło: T. Palmowski (2020) 
rowerowych łączących gminy powiatu, takie jak Czersk, Chojnice, Brusy i Konarzyny. Przebiega przez niezwykle atrakcyjne tereny ZPK, łączy m.in. Charzykowy i Swornegacie (szlak czerwony). Tylko na terenie ZPK znajdują się cztery szlaki rowerowe oraz pięć szlaków Kaszubskiej Marszruty. W ramach projektu powstało 165 km oznakowanych szlaków rowerowych. Część z nich $(61 \mathrm{~km})$ to specjalnie wybudowane ścieżki rowerowe, biegnące wzdłuż ruchliwych szos. Dodatkowo oznakowano 104 km szlaków rowerowych, prowadzących drogami asfaltowymi. Na trasie Kaszubskiej Marszruty umiejscowiono 12 miejsc odpoczynku, 42 tablice informacyjne, pięć kładek nad jarami i potokami. W ramach tego projektu przebudowano także most na Brdzie w Babilonie, zbudowano dwa przejścia dla płazów oraz most zwodzony w Małych Swornegaciach. W ramach Święta Powiatu Chojnickiego odbywa się Rajd Kaszubskiej Marszruty. Jego meta znajduje się w parku 1000-lecia w Chojnicach (Kaszubska Marszruta, 2019).

Na terenie gminy Chojnice budowane są kolejne ścieżki rowerowe, które łączą poszczególne części gminy z miastem Chojnice. Ten bezpieczny i ekologiczny sposób przemieszczania się cieszy się dużym zainteresowaniem mieszkańców i turystów. Do końca grudnia 2018 r. tylko w tej gminie powstało ponad $91 \mathrm{~km}$ ścieżek rowerowych (Kaszubska Marszruta, 2019).

\section{Podsumowanie}

W Monografii Wielkiego Pomorza i Gdyni, wydanej z okazji 20-lecia powrotu ziemi pomorskiej do Macierzy przez Wydawnictwo „Polska Niepodległa” Toruń-Lwów w 1939 r. $^{11}$, jej autorzy napisali: „Chlubą Chojnic jest Charzykowo, tuż obok Chojnic leżące, przepiękne miejsce klimatyczne, ośrodek żeglarski i wioślarski, cel wielu wycieczek, odpowiadający w całej pełni wymaganiom turystycznym i sportowym". Jak widać, po upływie ponad 80 lat historia kołem się toczy, a główna oś turystyczna Charzykowy-Swornegacie tylko zyskała na atrakcyjności. Dobrze, że w dokumentach strategicznych gminy Chojnice i powiatu chojnickiego kierunek poszanowania i ochrony środowiska oraz rozwoju turystyki, w tym odpowiedniej infrastruktury rowerowej, kajakowej i żeglarskiej, znajduje właściwe miejsce.

${ }^{11}$ Reprint tej publikacji ukazał się 2020 r. Wydawcą jest KSIEŻY MŁYN Dom Wydawniczy Michał Koliński, Łódź. 
W ostatnich latach gmina Chojnice nie tylko promuje swoje zasoby przyrodnicze, kulturowe oraz turystykę, realizuje także wiele inwestycji. Ważnym przedsięwzięciem, przyczyniającym się do wzrostu potencjału turystycznego gminy, była budowa ok. 100 km ścieżek rowerowych i infrastruktury turystycznej w ramach „Marszruty Kaszubskiej”. To atrakcja, która przyciąga aktywnych turystów z kraju i spoza jego granic. Jeśli dodamy do tego rozwijającą się stale bazę noclegową, regionalną kuchnię, piękne i czyste plaże oraz akweny, po których można żeglować i pływać kajakiem - pojawia się ciekawa i atrakcyjna oferta, z której warto skorzystać.

\section{Bibliografia}

Centrum Edukacji Przyrodniczej Parku Narodowego „Bory Tucholskie” w Chocińskim Młynie (2020). Pobrane z: http://www.pnbt.com.pl/centrum_edukacji_przyrodniczej_ parku_narodowego_bory_tucholskie_w_chocinskim_mlynie-668 (12.10.2020).

Gierańczyk, W. (2015). Społeczno-demograficzne uwarunkowania rozwoju strefy tranzytowej Rezerwatu Biosfery Bory Tucholskie. W: M. Kunz (red.), Stan poznania środowiska przyrodniczego Tucholskiego Parku Krajobrazowego i Rezerwatu Biosfery Bory Tucholskie (s. 273-284). Tuchola-Toruń: Uniwersytet Mikołaja Kopernika w Toruniu, Tucholski Park Krajobrazowy.

Gierszewski, C. (2008). Charzykowy moja żeglarska mała ojczyzna. Bydgoszcz-Chojnice: Logo.

Gmina Chojnice (2013). Ilustrowany przewodnik po gminie. Gdańsk: Wydawnictwo Eko-Kapio. Kaszubska Marszruta (2019). Promocja Regionu Chojnickiego. Wrocław: Studio Plan.

Knopek, J. (2018). Wypisy do „Dziejów Chojnic". Chojnice: Urząd Miejski w Chojnicach.

Marina Charzykowy (2020). Materiały niepublikowane Gminnego Ośrodka Kultury w Chojnicach.

Gminny Ośrodek Kultury w Chojnicach (2020). Pobrane z: https://www.gokchojnice.pl/ (12.10 2020).

Urząd Gminy Chojnice (2020). Dane pozyskane z Bazy noclegowej i Bazy gastronomicznej. Chojnice: Urząd Gminy Chojnice.

Lachowski, J. (red.) (1939). Monografia Wielkiego Pomorza i Gdyni. Toruń-Lwów: Wydawnictwo „Polska Niepodległa”.

Orłowicz, M. (1924a). Ilustrowany przewodnik po województwie Pomorskiem. LwówWarszawa: Książnica Polska.

Orłowicz, M. (1924b). Ilustrowany przewodnik po Ziemi Kaszubskiej. Lwów-Warszawa: Książnica Polska.

Ostrowski, K. (2009). Bedeker Chojnicki. Chojnice: Urząd Miejski w Chojnicach.

Palmowski, T. (1997). Ścieżki przyrodniczo-dydaktyczne w Borach Tucholskich. Kwartalnik Geograficzny, 1, 35-41.

Sołectwo Charzykowy (2020). Pobrane z: http://www.solectwo.charzykowy.pl/kolebka-zeglarstwa/historia/ (12.10.2020).

Zwoliński, G. (red.) (2020). Chojnice i okolice. Wrocław: Studio Plan. 


\title{
DAWNE I WSPÓŁCZESNE WALORY TURYSTYCZNE ZIEMI ZABORSKIEJ
}

\begin{abstract}
Abstrakt: Po odzyskaniu przez Polskę niepodległości wzrosło zainteresowanie Pomorzem. Mieczysław Orłowicz, znakomity polski krajoznawca kierujący w latach 1919-1923 Samodzielnym Referatem dla Spraw Turystyki w Departamencie Ogólnym Ministerstwa Robót Publicznych, w swoich licznych publikacjach, głównie przewodnikach, opisywał i popularyzował walory przyrodnicze i kulturowe wielu części naszego kraju, w tym Pomorza. Na podstawie wspomnianych opracowań w niniejszym artykule przybliżono ówczesny „klimat" części Pomorza zwanej Zaborami. Następnie zaprezentowano współczesny obraz turystyki na tym terenie. Zwrócono uwagę na walory środowiska przyrodniczego regionu i formy jego ochrony oraz atrakcje, pozwalające na aktywne uprawianie w tej części ziemi chojnickiej różnorodnych form turystyki. Uwzględniono także inwestycje w rozwój infrastruktury turystycznej, w tym rowerowej, kajakowej i żeglarskiej.
\end{abstract}

Słowa kluczowe: Zabory, ziemia chojnicka, Bory Tucholskie, Zaborski Park Krajobrazowy.

\section{TOURIST ASSETS OF ZABORY \\ IN CONTEMPORARY TIMES AND YEARS PAST}

\begin{abstract}
Interest in Pomerania developed after Poland regained independence. Mieczysław Orłowicz, a distinguished Polish 'excursionist' who managed the Tourist Section in the General Department in the Ministry of Public Works, brought to light and promoted in his numerous publications (mainly guidebooks) the cultural and natural environmental assets of many regions in the country including Pomerania. Based on these, the author sought to give a closer look at the part of Pomerania called Zabory. A picture of tourism in the area presented nearly a century ago is followed by that of today. The author draws attention to the natural environment of the region and environmental protection measures as well as the attractions offered by this part of the Chojnice district which favours various forms of active tourism. The article also refers to investments in tourist infrastructure including cycling, kayak and sailing facilities.
\end{abstract}

Keywords: Zabory, Chojnice district, Tuchola Forest, Zaborski Landscape Park. 